\title{
IOT IN THE WAKE OF COVID-19
}

\author{
Khadija BELASRI, Tomader MAZRI \\ University Ibn Tofail, National School of Applied Sciences Kenitra, Morocco - (khadija.belasri1, tomader.mazri)@uit.ac.ma
}

KEY WORDS: Iot, Covid-19, Telemedicine, Contact tracing, Monitoring.

\begin{abstract}
:
Healthcare is an imperative portion of life. Tragically, the exceptional outbreak of the 2019 novel coronavirus, named as COVID-19 by the World Health Organization (WHO), has strained the largest part of health systems and the request for resources from hospital packs to specialists and nurses have become extremely high. However, With the rise of the Internet of Things, new services in healthcare will be accessible and existing systems will be coordinated within the IoT system, giving automated medical supervision and efficient medical treatment, it is evident that a solution is necessary and required to promote the health sector in the era of Covid19 pandemic whereas proceeding to supply a high-quality care to patients. In this article, we shed light on a few of the issues and challenges related to the appropriation of portable contact tracing and monitoring of patients' arrangements for fighting COVID-19.
\end{abstract}

\section{INTRODUCTION}

The Internet of Things (IoT) is a concept that reflects the connections of anyone, anything, anytime, anywhere, any service and any network. (islam, kwak, kabir, Hossain, and Kwak 2015)

The Internet of Things (IoT) is a network of connected and intelligent physical devices. These devices have embedded software, sensors, and network connections that enable them to collect and exchange data. The Internet of Things can be remotely controlled across existing network infrastructure, which creates opportunities for more direct integration of devices into computer-based systems, thereby increasing efficiency and accuracy. This, in turn, provides economic benefits to those who use it. (Chacko, A., \& Hayajneh, T. 2018)

\section{COVID-19}

Coronavirus disease 2019 (COVID-19), also known as severe acute respiratory syndrome coronavirus 2 (SARS- CoV-2), was first reported in China in December 2019, and it was announced as a global epidemic on March 11th, 2020 by World Health Organization (WHO). Coronavirus spreads from person to person through coughing and sneezing. As of the end of June 2020, about 10 million cases have been reported and more than 500,000 deaths. (Raza, K., Maryam, \& Qazi, S. 2021)

During the lockdown situation, it is challenging for patients to go to hospitals. For the sake of the victims, most of the hospitals have initiated the services of telemedicine for infected individuals. Michalakis, K., \& Caridakis, G. (2017)

\section{TELEMEDICINE}

Telemedicine is a relatively new term which is being used intensively in this area. Telemedicine can be divided into two words; Tele which refers to use of modern communication schemes like wireless networks, and Medicine which is diagnosing a patient for any certain diseases and check patients wellness. (Mohamed, W., \& Abdellatif, M. M. 2019)

Moreover, known as telehealth, this practice permits clinicians to assess, analyze, and treat patient without requiring any physical interaction with them .(Tseng, V. S., Jia-Ching Ying, J., Wong, S. T. C., Cook, D. J., \& Liu, J. 2020)

\subsection{IoMT:}

The Internet of Medical Things (IoMT), also referred to as the healthcare IoT, is an amalgamation of medical devices and software applications offering extensive healthcare services, that are connected to the healthcare IT systems. (V. Hassija, V. Chamola, V. Saxena, D. Jain, P. Goyal, and B. Sikdar 2019) Owning to their capacity to gather, analyze, and transmit wellbeing information effectively, the wellbeing care division has realized the transformative potential of IoMT advances. (https://www2.deloitte.com/) The practice of utilizing Iomt advances to facilitate remote patient Checking is called telemedicine.

The benefits of receiving telehealth procedures have been twofold:

It has reduced the burden on the exhausted healing center staff. It has decreased the hazard of spread of the infection from the contaminated people to the healthcare staff.

\subsection{Highlights of the features of the technology IoMT in} Tacking COVID-19:

\begin{tabular}{|c|c|c|}
\hline $\begin{array}{l}\text { Emerging } \\
\text { technology }\end{array}$ & $\begin{array}{l}\text { Highlights of the } \\
\text { features of the } \\
\text { technology }\end{array}$ & Challenge \\
\hline $\begin{array}{l}\text { Internet of } \\
\text { Medical } \\
\text { Things }\end{array}$ & $\begin{array}{l}\text { Self-quarantine and self- } \\
\text { screening at home and } \\
\text { remotely send results to the } \\
\text { healthcare professionals. } \\
\text { Support remote } \\
\text { consultations between } \\
\text { healthcare professionals } \\
\text { and COVID-19 patients } \\
\text { using smart video } \\
\text { conferencing platforms } \\
\text { and telemedicine } \\
\text { Rapid COVID-19 } \\
\text { screening. }\end{array}$ & $\begin{array}{l}\text { Malicious } \\
\text { attack of IoMT } \\
\text { healthcare } \\
\text { equipment } \\
\text { could be a } \\
\text { drawback in } \\
\text { interconnected } \\
\text { IoMT } \\
\text { infrastructure }\end{array}$ \\
\hline
\end{tabular}

Table 1. presents a summary report of the features and challenge of the technology IoMT in tracking COVID-19 (Mbunge, E., Akinnuwesi, B., Fashoto, S. G., Metfula, A. S., \& Mashwama, P. 2021). 


\subsection{Various technologies enabling telemedicine:}

Within the past few months, a few telemedicine apparatuses like telemedicine carts, teleconsultation program, and portable tablets have proved their utility within the battle gainst the COVID-19 widespread. In any case, the true potential of telemedicine can as it were being realized when existing telemedicine platforms are used in conjunction with other advances such as drones, robots, smart wearables, and next-generation $5 \mathrm{G}$ cellular networks. (Chamola, V., Hassija, V., Gupta, V., \& Guizani, M. 2020)

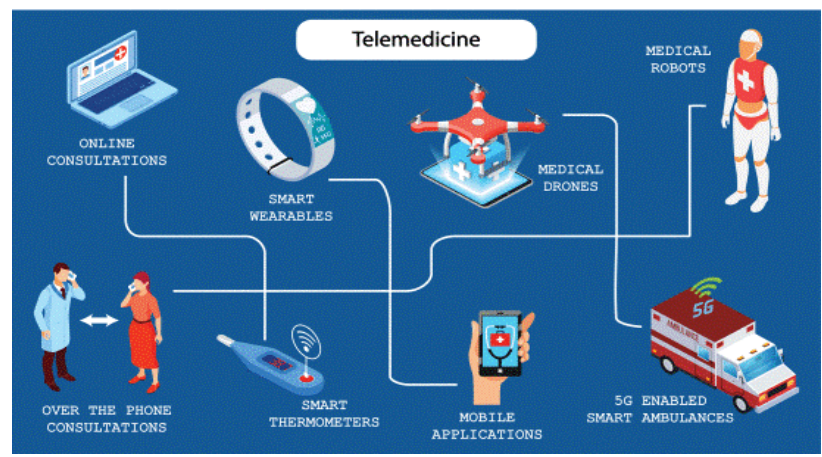

Figure 1. Various technologies enabling telemedicine

3.3.1 Mobile application: Have you ever wondered if we can really monitor the health status of an individual accurately or can a patient be treated at his home so wisely? It has been a challenge for years to improve our health system to gain better health services and treat patients in bad situations. Here, a simple term 'Mobile technology' comes into play which has the capability of improving the issues faced by the medical sciences and is therefore commonly known by the name of "mHealth". It is an emerging discipline, which is nowadays boosted up to a new and bigger, level due to ongoing pandemic coronavirus diseases (COVID-19) and has somewhere resulted in better output in health services. (Standing, S., \& Standing, C. 2008)

The role of mobile technologies is multifaceted and the translation of their diversified functionalities into real-world field studies is a reality. These plural functionalities turn into a broad range of solutions to address the needs of all targeted primary users categorised by the Classification of Digital Health Interventions: clients, health care providers, health system managers and data services. Within the context of the pandemic, their high usability allows for information dissemination, fastpaced contact tracing, telemedicine by mobile devices, real-time data collection, convenient monitoring of health status and effective control, which contributes to mitigate and prevent the spread of infections. WHO (2019)

When we come over a word Mobile innovation, each of us thinks about a technology which a mobile phone use. But it isn't true at all, it may be a sort of innovation which moves with the user, i.e. in straightforward words, a technology which goes where the user goes. It for the most part has numerous portable remote devices such as iPad, tablet, smartphone, smartwatch etc. which are for the most part associated by means of the systems like Wi-Fi, bluetooth, Worldwide Situating Framework (GPS), and cellular systems and share the voice, information, applications, records etc. (Raza, K., Maryam, \& Qazi, S. 2021)

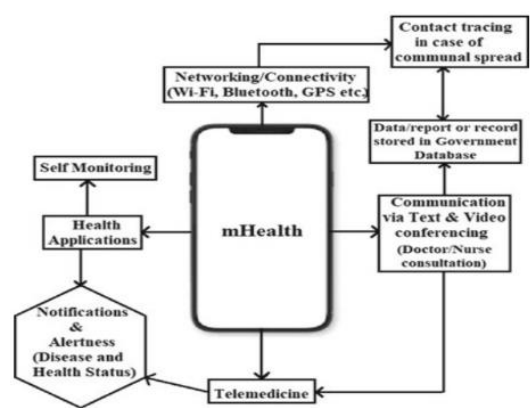

Figure 2. mHealth in Various Domains; explaining the importance of mHealth (Mobile health) and how it is working. (i) By text messaging and video conferencing, a patient can consult a doctor without travelling such a large distance and can get proper guidance and direction for the treatment of a particular disease

\section{HOW DOES THE TRACING OF COVID19 PATIENTS WORK?}

Contact Tracing is a key strategy for moderating the impact of diseases like COVID-19 on health care systems in particular and health of the populace in common, and is subsequently expected to slow the spread of infectious diseases. It allows individuals of a country or a community to relieve distress from a community's containment measures, as it gives the corresponding contaminated individuals a chance to isolate themselves deliberately. Contact tracing is anticipated to increase the sensitivity taken after by the readiness of a country, a community, or people for an emerging pandemic like novel Coronavirus (COVID-19) by moderating the as of now accessible flaws of the traditional discovery which exclusively depends on side effects. (Dar, A. B., Lone, A. H., Zahoor, S., Khan, A. A., \& Naaz, R. 2020).

According to WHO, contact-tracing happens in three steps:

1. Identifying the Contact: from the already affirmed positive cases, recognizing those that the patient had contact with (according to the transmission modalities of the pathogen).

2. Listing of Contacts: Keep a record of possible contacts of the infected patients and inform those individuals.

3. Contact Follow-Up: A necessary follow-up of the patients that are believed to have come in contact with the infected individuals and those who are positive.

\section{TRACKING/MONITORING COVID-19}

Mobile software applications which are being used amid the intense time of ongoing pandemic are called COVID-19 apps. Numerous applications were developed or proposed and are beneath the survey prepare with the officially supports of the government in a few regions and jurisdictions.

Numerous countries have developed contact tracing apps during the time of the ongoing pandemic, it could be a way better opportunity for the computer researcher and bioinformaticiens to assist medical staffs, hence in a really brief period, numerous applications have been launched to track and monitor the COVID-19 cases. These applications too offer assistance to keep the public safe and provide better precautious steps to live a COVID-19 free life. Few applications have been well described bellow 
The International Archives of the Photogrammetry, Remote Sensing and Spatial Information Sciences, Volume XLVI-4/W5-2021

The 6th International Conference on Smart City Applications, 27-29 October 2021, Karabuk University, Virtual Safranbolu, Turkey

\begin{tabular}{|l|l|l|l|}
\hline \multicolumn{1}{|c|}{ Country } & Application & platform & functionality \\
\hline Turkey & $\begin{array}{l}\text { Hayat Eve } \\
\text { Siğar }\end{array}$ & $\begin{array}{l}\text { iOS, } \\
\text { Android } \\
\text { and } \\
\text { Huawei } \\
\text { Stores }\end{array}$ & $\begin{array}{l}\text { HES codes, and } \\
\text { tracking system }\end{array}$ \\
\cline { 2 - 4 } & $\begin{array}{l}\text { The Spread } \\
\text { Project }\end{array}$ & $\begin{array}{l}\text { Android, } \\
\text { iOS }\end{array}$ & $\begin{array}{l}\text { Medical } \\
\text { reporting and } \\
\text { contact-tracing } \\
\text { application }\end{array}$ \\
\hline Canada & Covid shield & $\begin{array}{l}\text { Android, } \\
\text { iOS }\end{array}$ & Contact tracing \\
\hline China & $\begin{array}{l}\text { Alipay health } \\
\text { code }\end{array}$ & $\begin{array}{l}\text { Android, } \\
\text { iOS }\end{array}$ & Contact tracing \\
\hline Denmark & Smitter & $\begin{array}{l}\text { Android, } \\
\text { iOS }\end{array}$ & Contact tracing \\
\hline Finland & Ketju & $\begin{array}{l}\text { Android, } \\
\text { iOS }\end{array}$ & Contact tracing \\
\hline France & stopCovid & $\begin{array}{l}\text { Android, } \\
\text { iOS }\end{array}$ & Contact tracing \\
\hline
\end{tabular}

Table 2. IoMT applications

\section{APPLICATION OF IOMT IN FIGHTING COVID-19 PANDEMIC}

IoMT includes the application of Internet of Things concepts, devices, and principles in health and medical domains through interconnected medical equipment, smart health applications, and smart sensors (Swati \& Chandana2020). It moreover comprises of creating smart applications and smart wearable devices particularly for progressing health care delivery. Amid the COVID-19 pandemic, the IoMT changes how healthcare services are delivered, moving physical contact to remote health service delivery due to limited mobility. Typically, apparent by a few IoMT applications that are integrated into health systems to reduce the burden on the healthcare systems. (Mbunge, E., Akinnuwesi, B., Fashoto, S. G., Metfula, A. S., \& Mashwama, P. 2021).

A few countries counting the USA, China, Poland, Croatia, Australia, Russia, and Austria implemented telemedicine strategies such as live webinars, remote consultation, and video conferencing; telehealth and smart thermometers to battle COVID-19 pandemic (Vinay, Vikas, Vatsal, \& Mohsen, 2020).

\begin{tabular}{|c|c|c|c|}
\hline Author(s) & \begin{tabular}{|l|} 
loMT \\
applications
\end{tabular} & Activities & Country \\
\hline $\begin{array}{l}\text { (Li et al., } \\
2020 \mathrm{a}, \\
2020 \mathrm{~b})\end{array}$ & nCapp & $\begin{array}{l}\text { Establish an online } \\
\text { COVID-19 real-time } \\
\text { update database } \\
\text { Real-time updating of } \\
\text { models of COVID-19 } \\
\text { diagnosis } \\
\text { Guide healthcare } \\
\text { professionals to } \\
\text { administer COVID-19 } \\
\text { treatment }\end{array}$ & China \\
\hline $\begin{array}{l}\text { (Nasajpour } \\
\text { et al., } \\
\text { 2020) }\end{array}$ & DetectaChem & $\begin{array}{l}\text { Low-cost app for } \\
\text { Detecting COVID-19 } \\
\text { using survey data }\end{array}$ & USA \\
\hline $\begin{array}{l}\text { (Nataliya } \\
\& \\
\text { Nadezhda, } \\
\text { 2020) }\end{array}$ & \begin{tabular}{|l|} 
Social \\
Monitoring
\end{tabular} & $\begin{array}{l}\text { Tracking of COVID-19 } \\
\text { patients who are on } \\
\text { diagnosis }\end{array}$ & Russia \\
\hline $\begin{array}{l}\text { (Nasajpour } \\
\text { et al., } \\
2020 \text { ) }\end{array}$ & Selfie app & $\begin{array}{l}\text { Monitoring of COVID- } \\
19 \text { patients and } \\
\text { suspected individual by } \\
\text { requesting them to take } \\
\text { and send selfie pictures }\end{array}$ & Poland \\
\hline $\begin{array}{l}\text { (Kirsten et } \\
\text { al., 2020) }\end{array}$ & Stop Corona & $\begin{array}{l}\text { Create COVID-19 } \\
\text { awareness by frequently } \\
\text { sending notification on } \\
\text { contact-persons, signs } \\
\text { and symptoms, and } \\
\text { location } \\
\end{array}$ & Croatia \\
\hline $\begin{array}{l}\text { (Thiele, } \\
\text { 2020) }\end{array}$ & $\begin{array}{l}\text { Stopp } \\
\text { Corona }\end{array}$ & $\begin{array}{l}\text { Track COVID-19 } \\
\text { patients and to isolate } \\
\text { contact persons }\end{array}$ & Austria \\
\hline
\end{tabular}

Table 3. COVID-19 apps

\section{THE DEPLOYMENT OF TELEMEDICINE IN THE COVID CRISIS}

The current pandemic has put great pressure on hospitals and medical practices, which have had to reorganize and, often, cancel non-urgent treatments and interventions. This unprecedented health emergency rapidly changed the way doctors provide patient care.

\subsection{Telemedicine at the heart of the COVID crisis in Switzerland}

Rapidly, numerous countries, including Switzerland, embraced a methodology of remote sorting, screening and monitoring by teleconsultation of patients positive or suspected for SARS$\mathrm{CoV} 2$ and their contacts. Tools for self-assessment or even tracing of contact subjects with the sending of a notification to take the screening test are emerging.

7.1.1 The University Hospitals of Geneva (HUG): The University Hospitals of Geneva (HUG), which have been testing for a year with HUG @ home, a web application for carrying out teleconsultations assisted by a nurse present at the homes of patients returning from hospitalization. At the peak of the crisis, the number of teleconsultations by video surpassed 600 per week at the HUG before falling to less than 100 video consultations per week (Geissbuhler, A., \& Mazourikarker, S. 2020) 
7.1.2 HUG @ home: hug@home is an application developed following two HUG hackathons and funded by the HUG private foundation as well as the General Directorate of Health of the canton of Geneva. Until the profound change induced by the new coronavirus crisis, it was an assisted teleconsultation application, allowing nurses working in the Geneva home care institution or in medico-social establishments. to contact a HUG doctor on call to obtain medical advice by chat, audio or video consultation, in order to avoid transferring patients to the emergency room following a recent hospitalization at the HUG. This tool allows sending or receiving a secure attachment.

Monitoring of patients with covid-19: At the same time, this platform has been deployed to monitor patients infected or likely to be infected with COVID-19 and not hospitalized. The protocol created for the follow-up of these patients provides for contacting them on a regular basis and arrange to guarantee the favorable advancement of their state of health and the nonappearance of criteria for hospitalization. HUG @ home allows, by video, a better evaluation compared to a basic telephone call, 5 giving by video consultation the possibility of establishing visual contact, which is also reassuring in this anxiety-provoking context.

This tool also allowed vulnerable or quarantined caregivers to continue working from home safely.

Undoubtedly, using a secure double authentication system, caregivers can connect from their own tool (mobile, tablet, personal computer) using an internet connection (wifi or 4G) with the same level of security than at HUG (Vendeuvre, L., P., Lecygne, C., Jeannot, J., G., Spahni, S., Mazouri-Karker, S. 2020)

\subsection{Telemedicine at the heart of the COVID crisis in Belgium}

The principle consists of offering telemonitoring at home to Covid patients, which may be an exceptionally great solution for the patient to regain a certain level of comfort, with strict hospital monitoring.

The objective isn't to discharge everyone into nature, but only patients with a mild to moderate form of the coronavirus who do not require an oxygen treatment. (https://www.lavenir.net/cnt)

\subsection{1 mobile application called "3S Homecare":}

3S Home Care is an interactive tool facilitating autonomy at home. It contains a health diary and external visits, a reminder of the tasks and questionnaires to be completed. Using a tablet, the patient and the various interveners at home fill out the liaison book, mentioning the tasks, appointments made, etc The data is sent to the platform which sends the information to the healthcare experts in charge of the patient. These experts can therefore follow the progress of their patient on a daily basis. The $3 \mathrm{~S}$ Home Care platform is available everywhere, on the basic condition of having an Internet network. 3S Home Care is associated to the Walloon (Belgium) health network. (https://www.reseausam.be/article/fr/1158/3s-home-care)

\subsection{Remote monitoring platform of the COVID-19 | Ile- deFrance}

The COVIDOM application and platform allow patients who do not require hospitalization to benefit from remote monitoring at home via medical questionnaires and, if necessary, new treatment by their attending physician or a contact. telephone by the operators of a regional medical telemonitoring platform. This device makes it possible to secure the follow-up of all patients with or suspected of Covid-19 who are at home, to optimize medical time, and to intervene at the slightest sign of worsening of the disease.

\subsection{1 covidom}

Covidom allows automated follow-up of suspected or confirmed Covid-19 patients, who do not require hospitalization. This remote monitoring platform, set up by the Assistance Publique Hôpitaux de Paris ( AP-HP), supported by the Regional Health Agency ( ARS) and the Regional Union of Health Professionals ( URPS) Liberal Doctors, is based on a technical solution from Nouvéal. This device is not mandatory and is based on the consent of the patient. It is part of the care pathway for patients suspected of having presented symptoms of Covid-19 or a positive test. At any time, the patient is in control of his care path and can change his mind. The patient can choose to follow up via the Covidom application available on the stores, or via the dedicated Covidom website. Covidom is free, personalized and secure.

\section{Concretely, how does this happen:}

The doctor includes the patient in the Covidom process. A patient cannot register directly with Covidom. The patient receives their own identifiers inviting them to the first connection to the platform (website or mobile application). The patient answers a daily questionnaire according to the risk identified by the doctor. Depending on the response to the questionnaire, alerts may be generated. When an alert is generated, it is processed by the Covidom platform which gets in touch with the patient and takes the appropriate measures

(https://www.covidom-idf.fr/covidom/)

\section{CONCLUSION}

Too many research had been launched in the world wide, to improve the healthcare services in way to complement the existing ones. by introducing the huge potential of the Iot that make us stronger to face actual and probable pandemics which is the case for covid-19. Moreover, the security and privacy of people's health information is not totally guaranteed. Thus, further research is required to strengthen the current technologies and there is a strong need for the emergence of a robust computationally intelligent model for early differential diagnosis of COVID-19.

\section{REFERENCES}

Chacko, A., \& Hayajneh, T. (2018). EAI Endorsed Transactions Security and Privacy Issues with IoT in Healthcare. Ghent, 4(14), 1-7.

Chamola, V., Hassija, V., Gupta, V., \& Guizani, M. (2020). A Comprehensive Review of the COVID-19 Pandemic and the Role of IoT, Drones, AI, Blockchain, and 5G in Managing its Impact. IEEE Access, 8(April), 90225-90265. https://doi.org/10.1109/ACCESS.2020.2992341

Dar, A. B., Lone, A. H., Zahoor, S., Khan, A. A., \& Naaz, R. (2020). Applicability of mobile contact tracing in fighting pandemic (COVID19): Issues, challenges and solutions. Computer Science Review, 38, 100307. https://doi.org/10.1016/j.cosrev.2020.100307

Deloitte Centre for Health Solutions. (Jul. 2018). Medtech Internet Med. Things. [Online]. Available: https://www2.deloitte.com/content/ dam/Deloitte/global/Documents/Life-Sc\%iences-Health-Care/gx-

lshcmedtech-iomt-brochure.pdf 
The International Archives of the Photogrammetry, Remote Sensing and Spatial Information Sciences, Volume XLVI-4/W5-2021

The 6th International Conference on Smart City Applications, 27-29 October 2021, Karabuk University, Virtual Safranbolu, Turkey

Geissbuhler, A., \& Mazourikarker, S. (2020). La télémédecine au cEur de la crise COVID: Un boom inespéré! Revue Medicale Suisse, 16(706), 1694.

\section{https://www.covidom-idf.fr/covidom/}

https://www.lavenir.net/cnt/dmf20210408 01570649/des-patientscovid-19-renvoyes-chez-eux-pour-un-suivi-hospitalier-depuis-leurdomicile-un-projet-unique-dans-3-hopitaux-wallons

https://www.reseau-sam.be/article/fr/1158/3s-home-care

Islam, S. M. R., Kwak, D., Kabir, M. H., Hossain, M., \& Kwak, K. S. (2015). The internet of things for health care: A comprehensive survey. IEEE Access, 3. https://doi.org/10.1109/ACCESS.2015.2437951

Laure, D., Vendeuvre, P., Lecygne, C., Gabriel, J., Spahni, S., Mazourikarker, S., Télémédecine, L. A., \& Balbutiements, À. S. E. S. (2020). Télémédecine à 1 ' ère du hôpitaux universitaires de Genève. 1695-1698.

Mbunge, E., Akinnuwesi, B., Fashoto, S. G., Metfula, A. S., \& Mashwama, P. (2021). A critical review of emerging technologies for tackling COVID-19 pandemic. Human Behavior and Emerging Technologies, 3(1), 25-39. https://doi.org/10.1002/hbe2.237

Michalakis, K., \& Caridakis, G. (2017). IoT Contextual Factors on Healthcare. Advances in Experimental Medicine and Biology, 989, 189200. https://doi.org/10.1007/978-3-319-57348-9_16

Mohamed, W., \& Abdellatif, M. M. (2019). Telemedicine: An IoT Application for Healthcare systems. ACM International Conference Proceeding Series, 173-177. https://doi.org/10.1145/3328833.3328881

Raza, K., Maryam, \& Qazi, S. (2021). An Introduction to Computational Intelligence in COVID-19: Surveillance, Prevention, Prediction, and Diagnosis. In Studies in Computational Intelligence (Vol. 923). https://doi.org/10.1007/978-981-15-8534-0_1

Standing, S., \& Standing, C. (2008). Mobile technology and healthcare: The adoption issues and systemic problems. International Journal of Electronic Healthcare, 4(3-4), 221-235.

Tseng, V. S., Jia-Ching Ying, J., Wong, S. T. C., Cook, D. J., \& Liu, J. (2020). Computational Intelligence Techniques for Combating COVID19: A Survey. In IEEE Computational Intelligence Magazine (Vol. 15, Issue 4). https://doi.org/10.1109/MCI.2020.3019873

V. Hassija, V. Chamola, V. Saxena, D. Jain, P. Goyal, and B. Sikdar, “A survey on IoT security: Application areas, security threats, and solution architectures,"' IEEE Access, vol. 7, pp. 82721-82743, Jul. 2019.

World Health Organization (2019) WHO Guideline: Recommendations on Digital Interventions for Health System Strengthening. Geneva, Switzerland: World Health Organization. 